УДК $81 ’ 25$ '23

\title{
PSYCHOLINQUISTIC CONSIDERATIONS ON TRANSLATION PROCESS: ANALYSIS, CHALLENGES AND FURTHER DEVELOPMENT
}

\author{
Borshchovetska V. \\ borshchovetska@gmail.com \\ Білоиерківський наиіональний аграрний університет \\ Дата надходження 30.04.2018. Рекомендовано до друку 28.05.2018.
}

\begin{abstract}
This paper attempts to discover the problems and challenges in the cognitive research of translation process based on the review of the foreign present achievements in the theoretical and empirical researches of translation so as to determine the potential direction of development in cognitive translation studies. The aim of this paper is to discuss some developments in empirical translation research within a theoretical and cognitive perspective. The focus is on the research of memory system regarding translation process. The paper first gives a short general overview of the role of memory system, highlights some questions which affect the process of translation. The analysis of the research and overview on translation as a cognitive activity has been made. The main psycholinguistic models in translation process have been considered and analysed. Finally, some conclusions are drawn and perspectives for future research are outlined.
\end{abstract}

Key words: translation, cognitive, memory system, translation phases, psycholinguistic translation models

Борщовецкая В. Д. Белоцерковский национальный аграрный университет

Психолингвистические основы перевода: анализ проблемы, перспективы исследований

Аннотация. Статья рассматривает проблемы, исследуемые в работах зарубежных ученых, которые посвящены изучению когнитивных аспектов письменного перевода на теоретическом и эмпирическом уровнях с целью определения направления развития когнитивной области перевода. Целью статьи является изучение достижений в области перевода как с эмпирической, так и когнитивной точки зрения. Рассмотрены некоторые вопросы системы памяти, относящиеся к процессу перевода. В соответствии с результатами проведенного анализа перевод определен как когнитивная деятельность. Описаны фазы развития теории перевода. Проанализированы психолингвистические модели перевода.

Ключевые слова: перевод, когнитивный, система памяти, периоды теории перевода, психолингвистические модели перевода.

Борщовецька В. Д. Білоцерківський національний аграрний університет

Психолінгвістичні засади перекладу: аналіз, виклики, перспективи

Анотація. Вступ. Стрімкий розвиток досліджень 3 перекладу включає численні дослідження в галузі теорії дескриптивного перекладу, започаткованої Дж. Холмс, які поділяються на три категорії: спрямовані на власне продукт перекладу, функції перекладу та процес перекладу. Останній привертає велику увагу учених всього світу протягом останніх десятиріч ХХІ століття, оскільки він компілює дані суміжних наук, а саме: психології, когнітивної психології, когнітивної лінгвістики, нейрофізіології та комп'ютерної лінгвістики. Визначено нові підходи, напрямки і методи отримання інформації, в тому числі й про систему пам'яті для переробки інформації у процесі перекладу, а також описано когнітивну поведінку перекладача. Включаючи природу системи пам'яті, що лежить в основі перекладацької діяльності. Такий інтерес до когнітивної сторони перекладу зумовлює появу нових дослідженнь в цій сфері, що безумовно сприятиме розвитку теорії перекладу. Проте низка питань $є$ невирішеною і потребує подальших досліджень. Мета. Вивчити процеси пам'яті, що лежать в основі переробки вхідної інформації під час перекладу, проаналізувати ментальні процеси перекладача, вивчити етапи розвитку зарубіжної теорії перекладу та дослідити психолінгвістичні моделі процесу перекладу. Методи. Вивчення літературних джерел зарубіжних учених, присвячених дослідженню питань когнітивної сторони процесу перекладу, історії перекладацької науки. Результати. У цій роботі розглядаються питання, пов'язані з функціонуванням системи пам'яті, що лежить в основі функціонування процесу перекладу. Розглядаються питання: яким чином взаємодіють між собою вхідна інформація та короткочасна пам'ять, а також обсяг і час для іiі 
переробки та фактори, що впливають на іі переробку. Виділено три принципи переробки вхідної інформації. У результаті аналізу наукових джерел досліджено п’ять фаз еволюції перекладацької теорії. Досліджено та охарактеризовано психолінгвістичні моделі процесу перекладу, а саме: інтерпретаційна, психолінгвістична, когнітивно-психологічна, когнітивно-прагматична. Здійснено огляд міжнародних спілок, проектів, що займаються численними питаннями в галузі перекладу. Висновки. Таким чином, в статті вивчено функціонування процесів пам'яті, що лежать в основі переробки вхідної інформації під час процесу перекладу, проаналізовано ментальні процеси перекладача, досліджено етапи розвитку зарубіжної теорії перекладу та розглянуто психолінгвістичні моделі здійснення перекладу.

Ключові слова: переклад, когнітивний, система пам'яті, періоди теорії перекладу, психолінгвістичні моделі перекладу.

Introduction. A rapid development of translation studies evolves effective researches in the field of Descriptive Translation Studies outlined by James Holmes (1972), namely the product-, functionand process-oriented studies. With more research findings in the first two fields made in the latter part of the 20th century, the process-oriented research is of great attention for the researches in the first decade of the 21 st century, as it entails the theoretical data and the research methods from the neighboring disciplines, such as psychology, cognitive psychology, cognitive linguistics, neurophysiology and computational linguistics. New trends, approaches and methods of gathering data about translator cognitive behavior, including memory, have emerged with findings of the underlying nature of translation as a cognitive activity. Taking this into consideration, the role of memory system cannot be underestimated. The latest development in the translation process-oriented research is provoking some researchers to initiate the emergence of a cognitive translation studies.

Analysis of recent research and publications. Thus some of the scholars undertake the research on the knowledge and skills in translator's behavior (Wolf, 1996), others study the cognitive process of translation (Gutt, 1991; Shreve \& Angelone, 2010; O'Brien, 2011). Some of the researches are devoted to psychological mechanisms in second language processing (Brown \& Hulme, 1992; Schmidt, 1992), while others concentrates on cognition in learning and memory (Baddeley, 1990; Bower, 1989). However, some problems remain to be solved and some theoretical and methodological issues have to be considered.

The purpose. This article is going to emphasize aspects of underlying memory systems and second language input processing in translation studies based on the review of the present achievements in the translation studies, analyse the mental process of the translator, and review the phases of translation studies and the existing theoretical models of translation process.

Results. In the case of second language learning, we scrutinize the situation in which the following generalizations apply:

1) there is an existing knowledge system (the L1);

2) the cognitive abilities and schematic knowledge of the L2 learner are considerably greater than of the L1 learner;

3) a qualitatively different talent for learning languages is no longer available;

4) ongoing performance may have an impact upon the nature of language learning;

5) the role of memory functioning in an effective way to language learning must not be underestimated.

On this spot the relations between all the memory system instruments in language processing in translation studies have to be considered and discussed.

There are different views among scholars as to: a) the interaction of input and working memory, and $b$ ) the extent the input is processed directly by long term memory (Baddeley, 1990).

The latter challenges us to tackle a series of the following questions which spotlight particular aspects of memory functioning in translation studies: the factors that influence the input process; whether memory capacities are limited, and what reduces the efficiency of input processing during 
translation; if input features can be made more likely to be processed and how; if the awareness of the contents and operation of working memory matter; whether language systems are qualitatively different from the other systems; the way the working memory / long-term memory connection can produce change in long-term memory, rather than simply transfer the information; what types of analysis take place on working memory material, and if they are beneficial; the nature of the longterm memory storage system; if similar processing systems are used in similar ways by everyone; if output can be based on more than one system etc. (Baddeley, 1990).

The latest surveys in psycholinguistics suggest the answers to some of the questions given above. They definitely have significant implications for both second language acquisition and language teaching in the field of translation (Bower, 1989; Brown \& Hulme, 1992; Rimer, 2000).

More recently, cognitive psychology has drawn attention of many scholars in order to reanalyze the functioning of input in terms of attentional processes (Gass \& Selinker, 1986; VanPatten, 2000). They propose three principles for input processing during the translation activity. These are:

Principle 1: Input for meaning is processed by learners before the input for form as they at first process content words in the input. Besides they tend to processing lexical items to grammatical items for semantic information. Moreover processing more meaningful morphology takes place before less or non-meaningful morphology, e.g. simple past regular endings rather than redundant verbal agreement.

Principle 2: The informational or communicative content has to be processed by the learners at no or little cost to attentional resources.

Principle 3: The default strategies, that assign the role of agent to the first noun (phrase), are processed by learners as they come across them. This is so called the "first noun" strategy that can be outweighed by lexical semantics and event probabilities. To use other processing strategies learners need to assimilate other cues (e.g. case marking, acoustic stress etc.) into their developing system (Gass \& Selinker, 1986; VanPatten, 2000).

B. VanPatten (2000) argues: "The processing approach is compatible with some clear pedagogic goals. It suggests the usefulness of training language learners in effective processing, to make them more able to notice relevant cues in the input so that form-meaning links are more likely to be attended to" (VanPatten, 2000).

In a similar vein, Schmidt proposes: "the crucial construct of noticing to start to account for the way in which a) not all input has equal value and b) only that input which is noticed then becomes available for intake and effective processing" (Schmidt, 1992).

All those findings have contributed a lot to the cognitive aspects of translation study. The first endeavor to survey translation as a cognitive activity can be attributed to the late 1960s. Borrowing from neighbouring disciplines, such as cognitive psychology, psycholinguistics, cognitive science, translation studies have ranged from theoretical modelling to empirical and experimental studies. Studies concerning translation as a cognitive activity date back to the late 1960s and start from the Interpretive Theory of Translation, which was mentioned above, and the seminal work of Seleskovitch (1968) and Lederer (1981).

Over the past decades, the study of translation as a cognitive activity has become the focus of interest of many surveys. Some models of the translation process have been developed: Bell (1991), surmising on cognitive science, artificial intelligence, and systemic functional linguistics; Gutt (1991) and Alves (2003), using the framework of relevance theory; Kiraly (1995), drawing on psycholinguistics and sociology; Wilss (1996), hypothesizing on cognitive psychology. Various models of translation competence have been proposed, e.g. by Bell (1991), PACTE (1998). Scintists define three phases in the development of empirical and experimental research in translation (Alves \& et al., 2010). The first phase dates back to the early 1980s, and draws primarily on think-aloud protocols (Ericsson \& Simon, 1984) for data elicitation. Using this technique, the pioneering work of Krings (2001) 
declared about the first phase of translation process research. A second phase started in the mid1990s, when scholars considered characterisitics and accounts in more details. A multi-methodological perspective starting from the Social Sciences and other related disciplines, introduced the use of various data elicitation tools such as interviews, retrospective protocols, questionnaires, and also other psycho-physiological measurements tools were used. The second phase is characterized by the evolution of the key-logging software. These new tools have initiated vigorous analyses of larger sets of data possible. Consequently, the impact of translation technology, mainly the use of translation memory systems, also drew the attention of scholars (Dragsted, 2010). In the mid-2000s, a third phase originally dealt with the introduction of eye-tracking data to the triangulation approach in experimental research. O'Brien's survey (2011) was one of the first to combine eye-tracking and translation technology. Then series of surveys, aimed at exploiting eye-tracking data to justify assumptions not yet confirmed by key-logged data, were made (Alves et al., 2010). This leads to unveiling a new trend in empirical-experimental research. It is a result of the increasing interaction between humans and machines in the translation industry. This trend, introduced by Krings's (2001) pioneering work, laid the ground for a fourth phase in the development of the survey which draws on computational linguistics, studies of human-computer interaction.

It proves that empirical and experimental research make it possible to use different data elicitation techniques as a way of capturing the process-product interface in translation. Therefore, it is essential to work out a specific methodological framework for the study of translation as a cognitive activity. To that extent, further survey is essential to consolidate the research and to strengthen the interdisciplinary exchange. Furthermore, effort needs to be put into further psychological studies in translation process. Studies would then have a much greater power of generalization.

Further, in this article we are going to analyse the theoretical models of translation process, partly mentioned above. Several theoretical models used by the translators or interpreters have been suggested by researchers in the field of translation studies. Six of the most representative models are classified into three groups according to their theoretic basis: the Interpretive Theory of Translation, Psycholinguistic and Cognitive Psychology Models, and Cognitive Pragmatic Model.

The Interpretive Theory of Translation as one of the earliest attempts to the account of the translation process developed by Seleskovitch (1968) and Lederer (1981) who were the pioneers in a cognitive approach to translation process. They proposed the Interpretive Theory of Translation (ITT) to identify three interrelated phases of translation/interpreting process: understanding, deverbalization and re-expression. Understanding is the process of generating sense, involving not only the linguistic knowledge, but some others as well, e.g. encyclopedic and contextual knowledge. Memory, as it was already mentioned above, plays an important role. Short-term memory stores lexicon for a short time, and cognitive memory stores the whole range of knowledge. The final result of understanding is nonverbal synthesis. ITT postulates the existence of an intermediate phase of deverbalization between understanding and re-expression. Re-expression is based on the deverbalized sense, or the non-verbal synthesis rather than the linguistic form. It involves also the work of both linguistic and non-linguistic knowledge, and is similar to monolingual communication in that the intended meaning is expressed in the target language.

Psycholinguistic and Cognitive Psychology Models are developed on the data of cognitive sciences such as psycholinguistics, cognitive psychology, artificial intelligence and neuroscience. They share the hypothesis that translation is a process of decoding the source language and recoding the target language. One of the representative models is given by Bell (1991), who builds on the perspectives from systemic-functional linguistics and artificial intelligence to understand translation as one of the two phases of analysis and synthesis. The phase of analysis undergoes the specific stages of visual recognition of the words in the source text, semantic and pragmatic processing to generate a semantic representation with the work of an idea organizer and a planner. The final product of the analysis phase 
is the semantic representation, which is then reprocessed at the phase of synthesis through pragmatic, semantic and lexico-grammatical synthesizers to be encoded in the target language and generates the translated text (Bell, 1991, p. 55). Different from Bell, Kiraly (1995) took a cognitive and a social perspective to propose two models of the translation process: a social model and a cognitive model. In the social model, translation is taken to be an activity in three interrelated situational contexts, namely that of the source text, that of the target text and a translational context (Kiraly, 1995, p. 102). His cognitive model consists of information sources, intuitive workplace and controlled processing centre. At the intuitive workplace, the information sources are processed without any conscious control to perform translation. If problems emerge, they are reconsidered in the controlled processing centre and a strategy is chosen to deal with these problems. If the strategy failed to come up with a translation, the translation problem is sent back to the intuitive workplace for a second processing with the information yet not taken into account. If the problem remains unsolved, a tentative translation is given and accepted for lack of adequate information (Kiraly, 1995 pp. 101-102). Wilss (1996) argues that problem-solving and decision-making are the most relevant elements in translation. He takes a cognitive psychological perspective to view translation as a decision-making process involving knowledge-based intelligent activities. It requires the acquisition of organized knowledge. If schema is considered to be the mental representation of knowledge, then the central task of cognitive approaches to translation process is to investigate the way schemas operate. In problem-solving, the translator needs both declarative knowledge and procedural knowledge, and six phases are listed in problemsolving: identification of problems; clarification of problems; search and retrieval of relevant information; problem-solving strategies; choice of solution; and evaluation of solution. There is also the cognitive simplification to reduce inaccuracies in specific translators' acts. Translation process also involves translator/interpreter's cognitive efforts.

Cognitive Pragmatic Model has been suggested by Gutt (1991) who builds on relevance theory to develop a relevance model of translation. Gutt argues that translation is a case of optimal interpretive resemblance in which "two utterances, or even more generally, two ostensive stimuli, interpretively resemble each other to the extent that they share their explicatures and/or implicatures" (Gutt 1991, pp. 44). The translator's task is to transfer to the target readers or audience all relevant aspects clearly and inferentially conveyed by the source text. Gutt suggests that the relevance translation theory is helpful in understanding and explicating the mental facilities of the translator.

These theoretic models share some fundamental views about the mental process of the translator. Most of these models conceive translation as a cognitive process that is dynamic, interactive and nonlinear in its nature. It involves the work of both the uncontrolled and controlled, or automatic and non-automatic processing. Some consider it to consist in problem-solving and decision-making. Information sources are regarded as the most important, including the work of long-term and short-term memory. However, most of the models remain a theoretic hypothesis without much empirical evidence. Only ITT is based on the observations of the translation acts, but they focus on interpreting and their data gathered are too general. With the newly-emerging empirical research methods, there is an increasing need of models that are more relevant to the laboratory experiments to gather more specific information about the translator's mental traits in translation. While these models offering only imaginary thinking about what is happening in the mind of the translator, researchers seek for gathering more specific evidence of the translation actions, including data or observations from experiments to justify the theoretic hypothesis. The attempts to find answers to these questions among others characterize cognitive approaches to translation process in the first decade of the 21 st century.

As it is argued above, cognitive approaches to translation process develop from theoretic thinking to more empirical verification. In the past ten years, the latest trends of the process-oriented translation studies are marked by the new ways of data collecting, more delicate research design, better control of variables in the experiments, and the deepening integration of multidiscipline. 
Researchers from different countries and language background have formed a number of communities in carrying out empirical investigation from different perspectives on subjects from different backgrounds. These projects and communities include, among others, the TRAP and EYETO-IT at Copenhagen Business School in Denmark, LETRA at the Universidade Federal de Minas Gerais in Brezail, the PACTE group at the University of Barcelona and the PETRA project at the University of Granada in Spain, the TransComp project at the University of Graz in Australia, and the CTP project at the Zurich University of Applied Sciences in Swiss. Most of these projects involve researches from more than one country, for example the EYE-TO-IT project has the researchers from Australia, Bulgaria, Denmark, Finland, Norway and Sweden. These projects carry out process researches of the both translation students and professional translators with a wider range and bigger number of subjects, better control of variables and more language pairs involved. Research findings also appeared in special issues of influential journals, including a 2005 special edition of Meta with the title of "Processes and Pathways in Translation and Interpreting" and a 2009 special edition of Across Languages and Cultures entitled "Process Research into Translation Competence". These research journals have broadened our theoretical and methodological fields in translation process research. They show us not only what is potential in human mind, but also how we can go about exploring the mind to examine its contents. They represent the recent progress and latest trends in research design, methods and increasing interdisciplinarity in cognitive translation process research (Shreve \& Angelone, 2010, p. 2).

Despite the remarkable progress in data acquiring methods, research design, variable control, and project size in translation process research, the cognitive approaches to translation process as a relatively new phenomenon is facing some challenges and potential problems expected to emerge. A clear understanding of the challenges will give us a picture of what might be the future direction to develop the cognitive translation studies as theoretic framework.

Conclusion. Prospects for further research. All those discussions mentioned in this article and many others regarding the problem, which are going to come will contribute a lot to the problem of psychological aspects in effective translation teaching and learning. Meanwhile cognitive process that take place in translation need further research and exploration.

\section{REFERENCES}

Baddeley, A. (1990). Human memory: Theory and Practice. Needham Heights, MA: Allyn and Bacon. Bower, G.H. (1989). Mental imagery and associative learning and memory. In L.W. Gregg (Ed.), Cognition in learning and memory (pp. 51-58). New York: Wiley.

Brown, G.D.A. \& Hulme, C. (1992). Cognitive Psychology and Second Language Processing: The Role of Short-term Memory. In R.J. Harris, Cognitive Processing in Bilinguals (pp. 105-121). Amsterdam: North-Holland Elsevier Science Publishers B.V.

Gass, S.M. \& Selinker L. (1984). Second language Acquisition. An Introductory Course. Hillsday, New Jersey: Lawrence Erlbaum Associates Publishers.

Rimer, C. (2000). Kognitive Aspekte des Lehrens und Lernens von Fremdsprahen. Tübingen: Gunter Narr Verlag Tübingen.

Schmidt, R.W. (1992). Psychological mechanisms underlying second language fluency. Studies in second language acquisition, 14, 357-385.

VanPatten, B. (1996). Input processing and Grammar Instruction. New York: Ablex.

Williams M. \& Burden R. (1999). Releasing Unlimited Learning Potential. In D. J. Mandelsohn (Ed.), Expanding Our Vision. Insights for language Teachers (pp. 94-107). Oxford: Oxford University Press.

Alves, F. (2003). Triangulating Translation: Perspectives in Process-Oriented Research. Amsterdam \& Philadelphia: John Benjamins. 
Alves, F., Pagano, A., Neumann, S., Steiner, E. \& Hansen-Schirra, S. (2010). “Translation Units and Grammatical Shifts: Towards an Integration of Product- and Process-based Translation Research". In G. Shreve \& E. Angelone (Eds.), Translation and Cognition (pp. 109-142). Amsterdam \& Philadelphia: John Benjamins

Seleskovitch, D. (1968). L'interprute dans les confürences internatinales: problumes de langage et de communication. Paris: Minard.

Lederer, M. (1981). La Traduction Simultanüe. Paris: Minard.

Bell, R. (1991). Translation and Translating: Theory and Practice. London and New York: Longman.

Kiraly, D. (1995). Pathways to Translation: Pedagogy and Process. Kent: Kent State University Press.

Wilss, W. (1996). Knowledge and Skills in Translator Behaviour. Amsterdam and Philadelphia: John Benjamins.

Gutt, E.-A. 1991. Translation and Relevance: Cognition and Context. Oxford: Basil Blackwell.

Shreve, G. \& Angelone, E. (2010). “Translation and Cognition: Recent Development”. In G. Shreve \& E. Angelone (Eds.),Translation and Cognition, (pp. 1-13). Amsterdam \& Philadelphia: John Benjamins.

Ericsson, A. \& Simon, H. (1980). "Verbal Reports as Data". Psychological Review, 3, 215-251.

Krings, H.-P. (2001). Repairing Texts: Empirical Investigations of Machine Translation Post-editing Processes. Kent: Kent State University Press.

O’Brien, Sh. (2011). Cognitive Explorations of Translation: Eyes, Keys, Taps. London \& New York: Continuum.

Dragsted, B. (2010). "Coordination of Reading and Writing Processes in Translation: An Eye on Uncharted Territory”. In G. Shreve \& E. Angelone (Eds.), Translation and Cognition (pp. 41-62). Amsterdam \& Philadelphia: John Benjamins. 